\title{
The Economic Performance of Ethiopian Alcohol and Liquor Industry: With Reference to National Alcohol and Liquor Factory
}

\author{
Habtamu Legese \\ Head, Department of Economics, Raya University, Ethiopia
}

\begin{abstract}
Though improving the industrial sector has been a major focus for many developing countries including Ethiopia, satisfying studies have not conducted on the sector. This paper tried to evaluate the economic performance of alcohol and liquor factory with particular reference to National Alcohol and Liquor factory in terms of productivity, profitability, capacity utilization, marketing and the socio-economic contribution of the factory. The study used the descriptive method of data presentation and the main data source of the study was the published and unpublished document of the factory from the period 2011 to 2018. The findings show that the whole productivities, measured by total factor productivity index was almost stagnating in each production year of the study considers. Regarding market performance, the study found out that the factory promoted modern marketing strategy and it became beneficiary from the strategic location since it touches every part of the country through its product. Generally, the result of the study shows that even though the performance of the factory was increasing over the year under consideration, there is still a better way of increasing the performance of the factory. The study recommends for efficient utilization of the existing resource, technological advancement, managerial efficiency and incentives from the concerned body of the government.
\end{abstract}

Keywords: Industry, performance, evaluation, utilization, Ethiopia.

DOI: $10.7176 / J P I D / 48-02$

\section{Introduction}

Industrialization said to be the process of building up a nation's capacity to convert raw materials and other inputs to finished goods for other products or for final consumption and it is the engine for socio-economic transformation of countries. It is favored for creating employment opportunity, bringing competitive advantage, and generating dynamism in the economy. A glance at the successes of the developed world revealed that industrialization significantly increased production and productivity and hence it has successfully altered the economic structure as well as the social composition of the population. Industrialization and industrial development also signify the political power of countries and their relative influence across the globe (Sonobe \& Otsuka, 2011 and Mandara \& Ali, 2018).

Industrialization plays a vital role in the economic development of underdeveloped countries. Historical facts revealed that all the developed countries of the world broke the vicious circle of under development by industrialization. The history of Ethiopian manufacturing industry is more or less related to the post-Ethio- Italy war. In the second half of the 1940s, there were very few manufacturing industries, which accounted for only $1 \%$ of the national income. Industrialization really began in the 1950s and was consolidated in the following three successive five-year developments plans (Getnet \& Admit, 2005). Concerning industrial policy formulation in Ethiopia has undergone several changes across the regimes. The industrial policy menu and practice at one time or another consisted of market-oriented development (under the Imperial era and EPRDF regime), publicoriented (under Dergue), foreign dominating industrialization (under Imperial Regime), and domestic ownership (Under EPRDF), and import substitution Vs export promotion under all regimes (Kindeye, 2014).

Manufacturing sector is the most dynamic components of the industrial sector and the manufacturing industry is categorized in to many groups including; Apparel industry, Chemical industry and Allied industry, Electronic and Electrical Equipment industry, Fabricated metal industry, Food, and kindred industry, Furniture and Fixture industry, Industrial and Commercial machinery industry, Lather industry, Lumber, and Wood industry. Measuring analyzing and controlling instrument industry, Miscellaneous manufacturing industry, Paper and allied industry, Petroleum refining and related industry, Primary metal industry, Printing, Publishing and allied industry, Rubber, and miscellaneous plastic industry, Stone, Clay, Glass and Concrete industry, Textile mill industry, Tobacco industry, and Transportation equipment industry.

The development and well-industrial performance of the manufacturing industry would contribute a lot for the growth of the overall economy through creating employment opportunity, by contributing to foreign exchange saving, by increasing government revenue through taxation and there are many things, which add fuel to the engine of economic growth. Alcohol and liquor industry is one of the major categories of the manufacturing sector. In Ethiopia, the major producer of this product is National Alcohol and Liquor Factory, which was established when three previously private liquor factories were nationalized in 1976, earned 130 million birrs in the 2009/10 fiscal year. The factory produces $96 \mathrm{pc}$ alcohol for uses ranging from medical purposes to electronic equipment cleaning, and 13 different kinds of liquor ranging in alcohol content from 
15 percent to 45 percent. The company also export its produthe ct to countries like southern Sudan, United States, and Australia (NALF ,2017).

Production structure, as reflan ected by the relative contribution of the economic sectors to the overall national income of a country, is one of the key indicators of the degree of industrialization of an economy. In highly industrialized economies, the contribution of agriculture to the national income is very small and is estimated to be less than 5 percent, while the share of industry is about six times greater (Rama and Simon 2015). In line to this fact, the aim of the study is evaluating the economic performance and contribution of Ethiopian alcohol and liquor industry with reference to National Alcohol and Liquor Factory.

\subsection{Statement of the problem}

Ethiopia's economic success over the past decade is outstanding. With double-digit rates of GDP growth, 3 billion USD of Foreign Direct Investment (FDI) in 2016 (the second highest level of all LDCs), and strong assessments by international credit rating agencies, Ethiopia has made huge advances in its goal of reaching middle-income status by 2025 (SIRPA, 2017).

The manufacturing sector is the heart and soul of many developed and developing country's economy. Expansion and development of manufacturing sector stimulate another sector through producing and supply capital, intermediate and consumption good demanding by all another sector of the economy. Even if the Ethiopia manufacturing industry started in the 1920s with a simple processing technology that produces agricultural - based products but the sector is still an infant, dominantly semi-processing and performs under capacity. As a result, the growth and contribution of the sector to the Ethiopian economy is at its infant stage (Rama \& Simon 2015 and UNDP 2016).

Agriculture is still the mainstay and backbone of the Ethiopian economy contributing 41 percent of GDP while the share of services has substantively increased in the past years and reached 45 percent in 2014 . The contribution of the industrial sector, however, remains low hovering around 14 percent for the past several decades (UNDP, 2017). The Ethiopian economy where rain-fed agriculture continues to play a dominant role, while manufacturing accounts for only 5\% of GDP. The other major challenge for Ethiopian manufacturing is the ability to create jobs. The employment share of manufacturing remains below its 5\% contribution to GDP. One contributing factor for this outcome is the extremely low graduation rate of small enterprises into medium and large size categories (Admasu, 2017).

Specific problems in the manufacturing sector include foreign exchange constraints to imports, intermittent power interruption and limited access to electric energy, shortage and irregular supply of domestic raw materials due to weak linkages, limited access to and poor quality of internet services, and weak logistical support that leads to high transaction costs. These and other associated constraints contributed to limiting the average capacity utilization of the medium and large scale manufacturing industries at 67 percent in 2014. Improvement in capacity utilization, the incidence of favorable weather conditions for a relatively long period, and improved adaptation strategies towards volatile climatic conditions among agricultural households improve factor productivity (UNDP, 2016).

The successor to the GTP, the second growth and transformation plan (GTP II) which is currently under preparation is envisioned to focus on the industrial sector and particularly on increasing the contribution of the manufacturing sub-sector, which is targeted to reach at $18 \%$ of GDP from the current level of $4.4 \%$ in 2015 . Though the industrial sector is witnessing growth in all areas, its contribution to GDP and capacity to generate foreign exchange, as well as employment creation, has fallen short of the expected target. In order to realize the vision of reaching a middle-income country status by 2025 , the industrial sector also needs to compensate for the past short falls as well as achieve new targets that will be set in GTP II, which will definitely be higher than its predecessor (UNDP, 2017).

Firms using technology licensed from foreign companies (percentage of firms) in Ethiopia reported at $42.8 \%$ in 2011, according to the World Bank collection of development indicators and $4.3 \%$ have ISO certification as of 2015 , as compared to $12.03 \%$ in sub-Saharan Africa as of 2016 . As a result, about $92 \%$ of national exports are agricultural and service, while manufacturing accounts for about $8 \%$ of total exports in 2016 . Under the growth and transformation plan two (GTP II ), the government envisions to create a foundation for the industrial sector to take a leading role in the economy but the manufacturing industry is still straggling with the same challenges that gripped it for decades. Achieving Vision 2025, a plan to make Ethiopia the leading manufacturing hub in Africa, requires an annual manufacturing growth rate of 25 percent and an increase in manufacturing's share of GDP to 20 percent by 2025 . The evidence above suggests the economy may fall short of this ambitious target (Oqubay, 2018).

The overall goal of the industrial development strategy is to bring about structural change in the economy through industrial development. Specifically it is aimed at by increasing the share of the industry sector as \% of the GDP from the current $13 \%$ to $27 \%$ by 2025 , and also increasing the share of the manufacturing sector as $\%$ of the GDP from the current 4\% to 17\% by the year 2025 (Ministry of Industry, 2017). 
Generally, Measuring productivity and efficiency are very important when evaluating production units, the performance of different industries or that of a whole economy. It enables us to identify sources of efficiency and productivity differentials, which is essential to policies designed to improve performance of the manufacturing sector and to achive the target 2025 (Adm Reiffa et al, 2002).

\subsection{The objective of the study}

The general objective of this research is to assess the economic performance and contribution of the National Alcohol and Liquor Factory.

Specifically, the paper attempt to address the following

$>$ To examine the profitability, productivity, and employment generation of the factory.

$>$ To investigate whether the factory is in the desired track of maximum capacity utilization.

\subsection{Methodology}

This research uses secondary data. data, which relates to employment, financial performance, operational performance and market share obtained from the annual report, published and unpublished documents of the company. In addition, other information also collected from different web searches. The data were analyzed by using descriptive analysis and different economic performance indicators also used to show the performance of the company. The results of the analysis also presented in graphs, charts, and tables.

\section{Economic performance indicators}

Single-factor productivity measures reflect units of output produced per unit of a particular input: labor productivity is the most common measure of this type Single-factor productivity levels are affected by the intensity of use of the excluded inputs: two producers may have different labor productivity levels even though they use the same technology (Fabrizio Pompei, 2016).

Labor productivity: Labor productivity is the ratio of output to labor input for a specific time, say, a day or a week or a month or a year. The input of labor may be taken a number of workers or person-hours worked during the period. This ratio computed from one worker or for the plant as a whole depending on the need.

$$
\text { Labour productivity }=\frac{\text { value of output }}{\text { Payment for workers }}
$$

Capital productivity: is the ratio of total output to capital represents a stock of produced goods, which the can be associated with labor to produce goods, which may or may not be similar. It measured in machine hours. Capital productivity depends on the productivity of labor because every capital good (machinery) is operated by works. Capital productivity can simply have expressed as the ratio of total output in physical or value terms to the value of a physical unit of capital.

$$
\text { Capital productivity }=\frac{\text { value of the output }}{\text { Payment for capital }}
$$

Total factor productivity: is the ratio of net output (gross output intermediate good and service purchased) to the sum of associated labor and capital inputs. Total Factor Productivity (TFP) has the advantage to be invariant to the intensity of use of observable factor inputs TFP differences reflect shifts in the isoquants of a production function: variation in output produced from a fixed set of inputs. Higher-TFP producers will produce greater amounts of output with the same set of observable inputs than lower-TFP businesses (Fabrizio Pompei, 2016).

Meaning and concept of efficiency: The core of any economic activity, whether it is consumption or production anything else, is to strive for the maximum possible efficiency. Efficiency means the ability to do things right. It is an input-output relationship involving the achievement of output with possible least resource use, the physical resource use or the monetary aspect of resource use. Equivalently, it is the achievement of the maximum possible output with given resource use (Barthwal, 1984).

Profitability and its measurement: Profit refers to either total profit, which is the difference between total revenue and total cost of profit per unit of output. The term profitability in the abstract sense defined as the quality of being profitable, i.e. yielding profit or advantage. Profit is interpreted as the difference between the total expenses involved in making or buying of a commodity and the total revenue accruing from its sales. This difference, when expressed as a proportion of invested capital or current outlay or sales, shows the profitability of the business. Profitability also expressed as the proportion by which the price per unit sold would be greater than the average or marginal cost. This is a ratio on turnover, which called price- cost margin; (Barthwal, 1984). Profitability often measured by gross profit margin ratio and net profit margin ratio.

$$
\begin{aligned}
\text { Gross profit margin } & =\frac{\text { gross profit }}{\text { net sales }} \\
\text { Net profit margin } & =\frac{\text { Net profit }}{\text { Net sales }}
\end{aligned}
$$

Market and market share: Economist understand the term market, not any particular market place in which things are bought and sold, but the whole of any region in which buyers and sellers are in such free intercourse with one another that the price of the same goods tends to equality easily and quickly. The more the nearly the 
market is, the strong is the tendency for the same price to pay for the same things at the same time in all parties of the market.

Capacity and capacity utilization: The capacity of a given firm depends on labor, availability of raw materials working hour, the nature of machinery and other production factors. These components give an indication of whether the factory operates in its full capacity or not. For instance, if there is no well-trained labor power and if the given labor is not updated, etc. it is unquestionable the factory would tend to fail production capacity would, hence, change through time as new and modern machines replaced the old ones.

\section{Data Presentation and Analysis}

\subsection{Production analysis}

National Alcohol and Liquor Factory (NALF) is government-owned factory, produces and distributes various types of alcoholic products with different level of alcohol content such as Baro Gin 41\% alcohol, Ouzo $41 \%$ alcohol, double ouzo 43\% alcohol, Aperitif 30\% alcohol, Brandy 41\% alcohol, Limon liquor $41 \%$ alcohol, pineapple liquor 41\% alcohol, supermen liquor 24\% alcohol, Fernet 37\% alcohol, Bitter 15\% alcohol, pure alcohol 96\% alcohol, denatured alcohol 95\% alcohol, cognac 37\% alcohol contents. The factory supplies its product to the Ethiopian and foreign markets. The factory has been exporting its products to countries such as USA, Australia, Israel, and South Sudan.

A consumer's view on the quality of a certain brand of alcoholic liquor is influenced by a number of factors including the chemical and physical attributes of the alcoholic beverage, its package type, the brand, and the labeling. Alcoholic liquor is a drink the taste of which can be accustomed in a repeated consumption. The ordinary consumer will customarily evaluate the taste of the alcoholic liquor against the taste he/she regularly encounters, which indicates the importance of consistency in alcoholic liquor quality. The ideal alcoholic liquor must appear fresh, bright and without faults to the consumer and hence the quality is a matter of great concern. The alcoholic liquor must also be free from microorganisms to ensure wholesomeness and biological stability. Visually the finished alcoholic liquor must have an attractive color.

\subsubsection{Output growth}

Performance evaluation of an industry output trend and growth rate is one of the major indicators of any industries performance. The change in output is decomposed in two a change in output due to movement along production function (change in factor input) and change in output due to shifting in the production function(technological change) the source output growth those the sum of the combined factor input growth and the rate of technical change. The technical change includes all force that raises the combined productivity of all factor of production, which enables to produce a greater output with the same volume of input (Tamirat T.2014). At factory level, output depends on factors such as production capacity of the factory, quality, and quantity of labor, quality, and availability of raw material, market demand for the product, as a result, it is an important indicator of the performance of the industry.

The following table shows the annual production level of NALF in the subsequent eight years from $2011-$ 2018 and its percentage growth rate in monetary value.

Table 1: Value of annual output growth measured in Ethiopian currency (Birr)

\begin{tabular}{lll}
\hline Year & Value of annual output in (Birr) & Percentage growth rate \\
\hline $\mathbf{2 0 1 1 / 1 2}$ & $235,156,000$ & - \\
\hline $\mathbf{2 0 1 2} / \mathbf{1 3}$ & $303,843,000$ & $\mathbf{2 9 . 2 0}$ \\
\hline $\mathbf{2 0 1 3 / 1 4}$ & $328,878,000$ & $\mathbf{8 . 2 3}$ \\
\hline $\mathbf{2 0 1 4 / 1 5}$ & $427,271,000$ & $\mathbf{2 9 . 9 1}$ \\
\hline $\mathbf{2 0 1 5} / \mathbf{1 6}$ & $526,531,000$ & $\mathbf{2 3 . 2 3}$ \\
\hline $\mathbf{2 0 1 6} / \mathbf{1 7}$ & $669,988,000$ & $\mathbf{2 7 . 2 4}$ \\
\hline $\mathbf{2 0 1 7 / 1 8}$ & $724,301,000$ & $\mathbf{8 . 1 0}$ \\
\hline $\mathbf{2 0 1 8} / \mathbf{1 9}$ & $782,359,000$ & $\mathbf{7 . 4 2}$ \\
\hline
\end{tabular}

Source: Planning and monitoring department of the factory \& own computation

As seen in the above tables, the production growth of the factory fluctuates from one to the other production years throughout the production period included in the study. However, since the measure of production growth by using the value of annual output in the consecutive years of the production period does not consider the impact of inflation, as a result, it is important to measure production growth by using other mechanisms which exclude the effect of inflation such as output growth in a liter. 
Table 2: Output growths in litrs

\begin{tabular}{lllllll}
\hline Year & $\begin{array}{l}\text { Pure } \\
\text { alcohol }\end{array}$ & $\begin{array}{l}\text { Percentage } \\
\text { growth }\end{array}$ & $\begin{array}{l}\text { Denature } \\
\text { alcohol }\end{array}$ & $\begin{array}{l}\text { Percentage } \\
\text { growth }\end{array}$ & Liquor & $\begin{array}{l}\text { Percentage } \\
\text { growth }\end{array}$ \\
\hline $\mathbf{2 0 1 1} / \mathbf{1 2}$ & $2,013,635$ & - & 158,273 & - & $5,196,519$ & - \\
\hline $\mathbf{2 0 1 2} / \mathbf{1 3}$ & $2,103,378$ & $\mathbf{4 . 4 5}$ & 151,194 & $\mathbf{- 4 . 4 7}$ & $5,640,481$ & $\mathbf{8 . 5 4}$ \\
\hline $\mathbf{2 0 1 3} / \mathbf{1 4}$ & $1,890,105$ & $\mathbf{- 1 0 . 1 3}$ & 105,312 & $\mathbf{- 3 0 . 3 4}$ & $4,682,919$ & $\mathbf{- 1 6 . 9 7}$ \\
\hline $\mathbf{2 0 1 4} / \mathbf{1 5}$ & $2,254,855$ & $\mathbf{1 9 . 2 9}$ & 140,310 & $\mathbf{3 3 . 2 3}$ & $5,761,707$ & $\mathbf{2 3 . 0 3}$ \\
\hline $\mathbf{2 0 1 5} / \mathbf{1 6}$ & $3,245,410$ & $\mathbf{4 3 . 9 2}$ & 145,966 & $\mathbf{4 . 0 3}$ & $7,278,169$ & $\mathbf{2 6 . 3 2}$ \\
\hline $\mathbf{2 0 1 6} / \mathbf{1 7}$ & $3,497,865$ & $\mathbf{7 . 7 7}$ & 294,595 & $\mathbf{1 0 1 . 8 2}$ & $9,259,759$ & $\mathbf{2 7 . 2 2}$ \\
\hline $\mathbf{2 0 1 7} / \mathbf{1 8}$ & $4,490,539$ & $\mathbf{2 8 . 3 7}$ & 349,611 & $\mathbf{1 8 . 6 7}$ & $11,495,075$ & $\mathbf{2 4 . 1 0}$ \\
\hline $\mathbf{2 0 1 8} / \mathbf{1 9}$ & $4,864,190$ & $\mathbf{8 . 3 2}$ & 352,868 & $\mathbf{0 . 9 3}$ & $12,245,792$ & $\mathbf{6 . 5 5}$ \\
\hline
\end{tabular}

Source: Planning and monitoring department of the factory \& own computation

As it is clearly presented in the above table in the fiscal year of $2012 / 13$, there is a reduction in the production of national alcohol and liquor factory but the monetary value of the product increase by 8.23 from $2011 / 2012$.

\subsection{Profitability analysis}

A company should earn to survive and grow over a long period. Profit is the difference between total revenue and total cost over a period. Profitability ratio can be computed as a ratio of profitability in relation to sales and it provides an overall evaluation of the factory and its management. It measures the ability of the company to each positive rate of return for its stockholders. The two methods of measuring profitability is net profit margin and gross profit margin. The higher the net profit margin the better the profitability of the factory

Table 3: Profitability of NALF

\begin{tabular}{llll}
\hline Year & Net profit (NP) & Net sales (NS) & Net profit margin (NP/NS) \\
\hline $\mathbf{2 0 1 1 / 1 2}$ & $36,740,000$ & $188,004,000$ & $\mathbf{0 . 1 9 5}$ \\
\hline $\mathbf{2 0 1 2 / 1 3}$ & $44,110,000$ & $248,558,000$ & $\mathbf{0 . 1 7 7}$ \\
\hline $\mathbf{2 0 1 3} / \mathbf{1 4}$ & $62,033,000$ & $234,927,000$ & $\mathbf{0 . 2 5 4}$ \\
\hline $\mathbf{2 0 1 4 / 1 5}$ & $69,153,000$ & $301,983,000$ & $\mathbf{0 . 2 2 8}$ \\
\hline $\mathbf{2 0 1 5} / \mathbf{1 6}$ & $104,046,000$ & $383,548,000$ & $\mathbf{0 . 2 7 1}$ \\
\hline $\mathbf{2 0 1 6} / \mathbf{1 7}$ & $131,276,000$ & $475,039,000$ & $\mathbf{0 . 2 7 6}$ \\
\hline $\mathbf{2 0 1 7 / 1 8}$ & $180,996,000$ & $607,113,000$ & $\mathbf{0 . 2 9 8}$ \\
\hline $\mathbf{2 0 1 8} / \mathbf{1 9}$ & $200,827,000$ & $664,840,000$ & $\mathbf{0 . 3 0 2}$ \\
\hline
\end{tabular}

Source: Finance department of the factory and own computation

The ratio presented above establishes a relationship between net profit and sales (revenue) indicate management efficiency in manufacturing, administrating and selling of products. The profit margin in the above table was positive in the whole years and it varies from 17 to 30 percent. These show that the firm was profitable after all cost of production where covered.

\subsection{Productivity analysis}

Productivity is one of the most $t$ important factors in evaluating the performance of manufacturing industries. Generally, the analysis of productivity is important for the purpose of policy formulation. There are several concept and measurement of productivity used to essentially identify the relationship between input and output in the production process. According to the purpose of the analysis for which the concept is employed, productivity could measure the fruit fullness of human labor under varying circumstance or the efficiency within which resource as a whole including capital and labor employed in production. In order to measure the productivity of a firm, industry or economy, we need information on the outputs produced by the production unit for each period in the sample along with the average price received by the production unit in each period for each of the outputs (Erwin Diewert, 2001).

\subsubsection{Labour productivity}

The labor productivity is the ratio of output to labor input for a specific period, say a day, a week, a month or a year. Labour productivity is a revealing indicator of several economic indicators as it offers a dynamic measure of economic growth, competitiveness, and living standards within an economy. It is the measure of labor productivity (and all that this measure takes into account) which helps explain the principal economic foundations that are necessary for both economic growth and social development (Freeman, 2008).

Generally, workers' productivity varies from country to country and also within the same industry because of objective factors like tools, equipment, machinery, and other factors which workers cooperate to produce some output. While other factors will be considered with personal attitudes or qualities of workers and management. Labor productivity often used as a test of industrial efficiency and even as an index of economic 
development of every society.

Table 4: Labour Productivity of NALF

\begin{tabular}{llll} 
Year & $\begin{array}{l}\text { Value of annual production } \\
\text { in ETB }(\mathbf{V})\end{array}$ & $\begin{array}{l}\text { Payment for } \\
\text { worker }(\mathbf{P})\end{array}$ & $\begin{array}{l}\text { Value of annual production/ Payment } \\
\text { for the worker }(\mathbf{V} / \mathbf{P})\end{array}$ \\
\hline $\mathbf{2 0 1 1} / \mathbf{1 2}$ & $235,156,000$ & - & - \\
\hline $\mathbf{2 0 1 2} / \mathbf{1 3}$ & $303,843,000$ & $16,084,605.96$ & $\mathbf{1 8 . 8 9}$ \\
\hline $\mathbf{2 0 1 3} / \mathbf{1 4}$ & $328,878,000$ & $19,367,578.96$ & $\mathbf{1 6 . 9 8}$ \\
\hline $\mathbf{2 0 1 4} / \mathbf{1 5}$ & $427,271,000$ & $20,767,590.96$ & $\mathbf{2 0 . 5 7}$ \\
\hline $\mathbf{2 0 1 5} / \mathbf{1 6}$ & $526,531,000$ & $28,637,609.17$ & $\mathbf{1 8 . 3 8}$ \\
\hline $\mathbf{2 0 1 6} / \mathbf{1 7}$ & $669,988,000$ & $40,919,933.18$ & $\mathbf{1 6 . 3 7}$ \\
\hline $\mathbf{2 0 1 7} / \mathbf{1 8}$ & $724,301,000$ & $46,246,166.80$ & $\mathbf{1 5 . 6 6}$ \\
\hline $\mathbf{2 0 1 8} / \mathbf{1 9}$ & $782,359,000$ & $57,387,417$ & $\mathbf{1 3 . 6 3}$ \\
\hline
\end{tabular}

\subsubsection{Multifactor productivity}

To measure total factor productivity, the study uses a ratio method, which is output divided by total factor cost. This ratio tells the value of output that the company produces out of one-birr worth of factors of production.

The ratio of output and combined capital and labor input Multifactor productivity $(\mathrm{MFP})=\frac{Q}{\boldsymbol{F}(L, K)}$

Indicates how efficiently combined labor and capital are used in the production

The total factor productivity of a firm, industry or group of industries is defined as the real output produced by the firm or industry over a period divided by the real input used by the same set of production units over the same period. However, it turns out to be difficult to provide a meaningful definition of real output or real input due to the heterogeneity of outputs produced and inputs utilized by a typical production unit. On the other hand, it is possible to provide meaningful definitions of output growth and input growth between any two-time periods using index number theory.

Table 5: Multifactor productivity of NALF

\begin{tabular}{llll}
\hline Year & Value of annual output & Cost of production $(\mathbf{C})$ & Multifactor productivity (C /V) \\
\hline $\mathbf{2 0 1 1} / \mathbf{1 2}$ & $235,156,000$ & $91,922,000$ & $\mathbf{2 . 5 5}$ \\
\hline $\mathbf{2 0 1 2} / \mathbf{1 3}$ & $303,843,000$ & $172,875,000$ & $\mathbf{1 . 7 5}$ \\
\hline $\mathbf{2 0 1 3} / \mathbf{1 4}$ & $328,878,000$ & $144,624,000$ & $\mathbf{2 . 2 7}$ \\
\hline $\mathbf{2 0 1 4} / \mathbf{1 5}$ & $427,271,000$ & $189,875,000$ & $\mathbf{2 . 2 5}$ \\
\hline $\mathbf{2 0 1 5} / \mathbf{1 6}$ & $526,531,000$ & $218,851,000$ & $\mathbf{2 . 4 0}$ \\
\hline $\mathbf{2 0 1 6} / \mathbf{1 7}$ & $669,988,000$ & $330,102,000$ & $\mathbf{2 . 0 2}$ \\
\hline $\mathbf{2 0 1 7} / \mathbf{1 8}$ & $724,301,000$ & $351,425,000$ & $\mathbf{2 . 0 6}$ \\
\hline $\mathbf{2 0 1 8} / \mathbf{1 9}$ & $782,359,000$ & $358,286,000$ & $\mathbf{2 . 1 8}$ \\
\hline
\end{tabular}

Source: Planning and evaluation department of the factory and own computation

The last column of the table tells that the totals factor productivity of the factory lay between 1.75 to 2.55 , which is almost uniform in the years the studies considered. In the year 2011 the factory was able to register highest total factor productivity ratio about 2.55 it implies out of the total factors of production that cost one birr the factory able to produce an output that worth 2 birrs and 55 cents.

\subsection{Marketing Analysis and Sales}

Marketing is a term used to cover those activities of firms associated with the sales and distribution of products. The market structure exerts considerable influence on the economic efficiency (performance) of a firm. It is the final activities undertaken by the firms in pursuit of their goals.

The volumes of sales of a firm give us some indication about the activates and its successfulness in business. As table size below shows the sales growth of the factory was increasing from years to years except for the decreasing rate in the year 2012/12 the factories sales volume decrease by $5.48 \%$ than the previous years Table 6: Sales and sales growth in Birr

\begin{tabular}{lllll}
\hline Year & Liquor & Pure alcohol & Denature alcohol & Total percentage growth \\
\hline $\mathbf{2 0 1 1} / \mathbf{1 2}$ & $182,620,000$ & $2,340,000$ & $3,004,000$ & - \\
\hline $\mathbf{2 0 1 2} / \mathbf{1 3}$ & $244,087,000$ & $1,392,000$ & $3,079,000$ & $\mathbf{3 2 . 2 0}$ \\
\hline $\mathbf{2 0 1 3} / \mathbf{1 4}$ & $230,883,000$ & 300,000 & $3,744,000$ & $\mathbf{- 5 . 4 8}$ \\
\hline $\mathbf{2 0 1 4} / \mathbf{1 5}$ & $297,643,000$ & 398,000 & $3,942,000$ & $\mathbf{2 8 . 5 4}$ \\
\hline $\mathbf{2 0 1 5} / \mathbf{1 6}$ & $378,785,000$ & $1,742,000$ & $3,021,000$ & $\mathbf{2 7 . 0 0}$ \\
\hline $\mathbf{2 0 1 6} / \mathbf{1 7}$ & $467,909,000$ & $2,366,000$ & $4,764,000$ & $\mathbf{2 3 . 8 5}$ \\
\hline $\mathbf{2 0 1 7 / 1 8}$ & $596,929,000$ & $4,102,000$ & $6,082,000$ & $\mathbf{2 7 . 8 0}$ \\
\hline $\mathbf{2 0 1 8} / \mathbf{1 9}$ & $654,028,000$ & $3,543,000$ & $7,270,000$ & $\mathbf{9 . 5 0}$ \\
\hline
\end{tabular}

Source: Finance department of the factory and own computation 


\subsubsection{Distribution}

Distribution refers to the distribution of the product to the consumers by the producer while channel of distribution is the network of intermediaries through whom the products flow till it finally reaches to the hands of the actual users or consumers. Intermediary sellers who intervene between the original source of supply and the ultimate consumer characterize an advanced marketing economy. These middlemen include retailers and whole sealers and many specialized types of merchants, brokers and sales agents" (Alderson, 1965). It becomes difficult for a manufacturer to adequately follow market trends and serve target markets if a proper distribution channel and organizational set up are not in place. Some markets are excessively supplied, while others experience frequent shortages. Intermediaries often and deliberately introduce artificial shortages in some brands to boost the marketability of a weaker brand. Currently, the distribution channel of NALF and other liquor producers in the country is a combination of:

Factory $\rightarrow$ Agent $\rightarrow$ Retailer $\rightarrow$ Consumer

Factory $\rightarrow$ Retailer $\rightarrow$ Consumer

Factory $\rightarrow$ Consumer

NALF employs three types of distribution arrangements. In Addis Ababa and its surroundings; the factory distributes the products to retailers directly using its own vehicles and directly sell to consumers from factory premises. In other routes, it distributes through agents.

The local market offers large and rapidly growing markets for alcoholic liquor. However, final consumers are widely scattered in different geographical area of the country. Therefore, the existing number of agents employed by the factory will not be able to efficiently cover the whole market. Moreover, there is overlapping of agent's territory in some areas. The core problem revolves around the lack of effective and efficient regional distribution network covering the entire market in the country. Currently and also in the past, distribution has been centered at Addis Ababa (where the factory distributes its products using agents and also directly to retailers and consumers). Lack of branch sales outlets and/or a sufficient number of agents and clear market territories of agents has resulted in the failure of the factory's products reaching regional markets.

\subsubsection{Advertisement}

Consumers often rely on information for their purchases. Without advertising, few consumers would be exposed to the variety of existing products, the price distribution, and the location of specific products. Advertising can serve as a tool for transmitting this information to consumers and therefore it should not be considered as an unnecessary activity (Oz Shy, 1995).

Table 7: Expenditure on advertisement

\begin{tabular}{|c|c|c|c|}
\hline Year & $\begin{array}{l}\text { Value of annual production (in } \\
\text { birr) }\end{array}$ & $\begin{array}{l}\text { Expenditure } \\
\text { advertisement }\end{array}$ & $\begin{array}{l}\text { Impact } \\
\text { advertisement }\end{array}$ \\
\hline 2011/12 & $235,156,000$ & - & \\
\hline 2012/13 & $303,843,000$ & $403,721.46$ & + \\
\hline $2013 / 14$ & $328,878,000$ & $640,991.35$ & + \\
\hline $2014 / 15$ & $427,271,000$ & $552,430.84$ & + \\
\hline $2015 / 16$ & $526,531,000$ & $1,888,512.99$ & + \\
\hline 2016/17 & $669,988,000$ & $1,865,474, .84$ & + \\
\hline $2017 / 18$ & $724,301,000$ & $2,294,593.40$ & + \\
\hline 2018/19 & $782,359,000$ & $2,010,252.00$ & + \\
\hline
\end{tabular}

Source: Finance department of the factory and own computation

\subsection{Capacity Utilization Analysis}

Manufacturing capacity utilization, value added and employment generation were regressed on the index of industrial productivity (which served as the proxy for industrial development) (Simon-Oke, 2005). Capacity utilization is simply the ability to produce a unit of product by effectively utilizing the scarcer resources of the economy. Full capacity has been variously defined as a minimum point on a cost function, a full input point on an aggregate production function, and a bottleneck point in a general equilibrium system. Full capacities should be defined as an attainable level of output that can be reached under normal input conditions-without lengthening accepted working weeks, and allowing for usual vacations and for normal maintenance (Lawrence,1966).

The capacity of a given firm depends on labor, availability of raw materials, working hour, nature of the machine and other production factors. These components give an indication of whether the factory operates in its full capacity or not. In the production process, every industry is expected to have some target output. In addition, the achievement of this target is one of the firm's capacities. However, planes may sometimes overstate because of management inefficiency in planning.

Having this in mind, we can see the volume of actual production, planned production, and percentage achievement. 
Table 8: Capacity utilization from design capacity perspective

\begin{tabular}{|l|c|c|c|c|c|c|c|c|c|}
\hline \multirow{2}{*}{ Year } & \multicolumn{3}{|c|}{ Liquor } & \multicolumn{4}{c|}{ Pure Alcohol } & \multicolumn{3}{c|}{ Denatured Alcohol } \\
\cline { 2 - 11 } & Plan & Achieved & $\mathbf{9}$ & Plan & Achieved & $\mathbf{\%}$ & Pan & Achieved & $\mathbf{\%}$ \\
\hline $2011 / 12$ & $4,340,808$ & $5,196,519$ & $\mathbf{1 2 0}$ & $1,786,320$ & $2,013,635$ & $\mathbf{1 1 3}$ & 128,796 & 158,273 & $\mathbf{1 2 3}$ \\
\hline $2012 / 13$ & $4,226,973$ & $5,640,481$ & $\mathbf{1 3 3}$ & $1,695,216$ & $2,103,378$ & $\mathbf{1 2 4}$ & 120,795 & 151,194 & $\mathbf{1 2 5}$ \\
\hline $2013 / 14$ & $4,304,800$ & $4,682,919$ & $\mathbf{1 0 9}$ & $1,691,813$ & $1,890,105$ & $\mathbf{1 1 2}$ & 142,350 & 105,312 & $\mathbf{7 4}$ \\
\hline $2014 / 15$ & $4,377,497$ & $5,761,707$ & $\mathbf{1 3 2}$ & $1,715,400$ & $2,254,855$ & $\mathbf{1 3 1}$ & 121,428 & 140,310 & $\mathbf{1 1 6}$ \\
\hline $2015 / 16$ & $6,717,002$ & $7,278,169$ & $\mathbf{1 0 8}$ & $2,697,600$ & $3,245,410$ & $\mathbf{1 2 0}$ & 180,360 & 145,966 & $\mathbf{8 1}$ \\
\hline $2016 / 17$ & $8,896,725$ & $9,259,759$ & $\mathbf{1 0 4}$ & $3,790,000$ & $3,497,865$ & $\mathbf{9 2}$ & 233,800 & 294,595 & $\mathbf{1 2 6}$ \\
\hline $2017 / 18$ & $10,548,528$ & $11,495,074$ & $\mathbf{1 0 9}$ & $4,279,500$ & $4,490,539$ & $\mathbf{1 0 5}$ & 342,360 & 349,611 & $\mathbf{1 0 2}$ \\
\hline $2018 / 19$ & $12,245,782$ & $12,245,792$ & $\mathbf{1 0 0}$ & $5,297,280$ & $4,864,190$ & $\mathbf{9 2}$ & 450,269 & 352,868 & $\mathbf{7 8}$ \\
\hline
\end{tabular}

Sours; Planning and evaluation department of the factory \& own computation

As we can see from the above table the percentage achievements of the factory was above the plan of the company except for the decrease in achievement in the product of Pure Alcohol and Denatured Alcohol by the year 2013/14, 2015/16 and 2017/18.

\subsection{Contribution of the Factory}

The establishment of the large factory had made a different contribution in assisting the development of the country. NALF is one of the largest factories in Ethiopia and contributes for the development of the country in different ways including employment generation, foreign exchange contributions, a a source of government revenue through tax and in supporting social activities.

\subsubsection{Foreign Exchange Generation (Contribution) Of NALF}

One of the economic problems of most developing countries is the shortage of foreign currency. Almost all developing countries have an infant manufacturing sector. As a result, they import products like medicine, capital goods, and other consumer goods from abroad. Due to the above facts, most LDCs suffer from a shortage of foreign currency. The NALF supplies its product to the Ethiopian and foreign market including the markets of USA, Australia, Israel, and South Sudan.by doing that the factory is doing its best to reduce the problem of foreign currency shortage.

Table 9: Foreign exchange earning

\begin{tabular}{lll}
\hline Year & Value of export in Birr & Percentage growth \\
\hline $\mathbf{2 0 1 1 / 1 2}$ & $6,405,000$ & - \\
\hline $\mathbf{2 0 1 2} / \mathbf{1 3}$ & $10,789,000$ & $\mathbf{6 8 . 4 4}$ \\
\hline $\mathbf{2 0 1 3} / \mathbf{1 4}$ & $12,950,000$ & $\mathbf{2 0 . 0 2}$ \\
\hline $\mathbf{2 0 1 4 / 1 5}$ & $4,376,000$ & $\mathbf{- 6 6 . 2 0}$ \\
\hline $\mathbf{2 0 1 5} / \mathbf{1 6}$ & $1,936,000$ & $\mathbf{- 5 5 . 7 5}$ \\
\hline $\mathbf{2 0 1 6} / \mathbf{1 7}$ & $1,636,000$ & $\mathbf{- 1 5 . 4 9}$ \\
\hline $\mathbf{2 0 1 7 / 1 8}$ & $3,183,000$ & $\mathbf{9 4 . 5 5}$ \\
\hline $\mathbf{2 0 1 8} / \mathbf{1 9}$ & $6,338,000$ & $\mathbf{9 9 . 1 2}$ \\
\hline
\end{tabular}

Source; planning and evaluation department of the factory the factory and own computation

As can be seen in the above table, the factory contributes a lot in generating foreign currency for the country. However, the percentage growth varies from one production year to the other. This is because of variations in production and level of exports.

\subsubsection{Employment Generation}

NALF create job opportunity for more than 680 people thereby absorbing a certain number of the labor force and reducing the level of unemployment, which is one of the serious problems facing here in Ethiopia.

Table 10: Employment from 2011/12 to 2018/19

\begin{tabular}{lll}
\hline Year & No of worker & Growth rate \\
\hline $2011 / 12$ & 600 & - \\
\hline $2012 / 13$ & 579 & $\mathbf{- 3 . 5}$ \\
\hline $2013 / 14$ & 532 & $\mathbf{- 8 . 1 1}$ \\
\hline $2014 / 15$ & 517 & $\mathbf{- 2 . 8 7}$ \\
\hline $2015 / 16$ & 557 & $\mathbf{7 . 7 3}$ \\
\hline $2016 / 17$ & 631 & $\mathbf{1 3 . 2 8}$ \\
\hline $2017 / 18$ & 693 & $\mathbf{9 . 8 2}$ \\
\hline $2018 / 19$ & 682 & $\mathbf{- 1 . 5 8}$ \\
\hline
\end{tabular}

Source: Department of human resource management \& own computation

Establishment of the large factory had made a different contribution in assisting the development of the 
given country. One of the contributions will be generating revenue for the government through taxation.

\subsubsection{Contribution in Supporting Social Activity}

Apart from producing and selling the products, NALF participates in the different social and economic activity of the country. Frome longer year experience the factory participate in the various actions and has made a thankful contribution to enrich the material and spiritual value of the society, eliminate the social and economic problem of the country.

Table10: All rounded contribution of the factory

\begin{tabular}{ll}
\hline Year & Cost of project \\
\hline $\mathbf{2 0 1 4 / 1 5}$ & 84,000 \\
\hline $\mathbf{2 0 1 5} / \mathbf{1 6}$ & 517,000 \\
\hline $\mathbf{2 0 1 6 / 1 7}$ & 157,000 \\
\hline $\mathbf{2 0 1 7 / 1 8}$ & 239,000 \\
\hline $\mathbf{2 0 1 8} / \mathbf{1 9}$ & 836,000 \\
\hline
\end{tabular}

Source: Planning and evaluation department of the factory

\section{CONCLUSION AND POLICY IMPLICATION}

\subsection{Conclusions and policy recommendation}

The paper concentrated on the economic performance of Ethiopian alcohol and liquor industry with particular reference to NALF and it was evaluated based on the productivity of major inputs, the profitability of the factory, capacity utilization of the factory, and marketing performance. In addition to this, the study sees the contributions of the factory in employment generation, in generating foreign exchange, in generating government revenue, and other activities in order to capture the full performance of the factory. In general, the overall productivity and profitability were rising on the particular year considered. This high rate of market share, productivity and profitability do not necessarily imply a better position.

With the existing resource, the company performs a lot better than this by working for efficient utilization of an existing resource, efficiency in management, resource use and technological advancement. In order to improve the productivity of employees, the factory should give pre-employment technical skill training for school levers and work training in workplace, set good employment monitoring practices like micromanagement, trust employees to do their jobs and give them the freedom to work in their individual styles. Let them know they are trusted while encouraging motivating them.

\section{Reference}

Adam Reiffa et al (2002). Analysis Of The Hungarian Economy: Productive Efficiency In The Hungarian Industry. Hungarian Statistical Review, Special number 7. 2002

Admasu Shiferaw (2017). Productive Capacity and Economic Growth in Ethiopia. CDP Background Paper No. 34, ST/ESA/2017/CDP/34.

Admasu Shiferaw (2017). Productive Capacity and Economic Growth in Ethiopia. CDP Background Paper No. 34. ST/ESA/2017/CDP/34.

Alderson, W. (1965). Dynamic Marketing Behavior. A Functionalist Theory of Marketing. Homewood: Richard D. Irwin.

Bartwal (1984). Industrial Economics : An Introductory Text Book

Erwin Diewert (2001). The Challenge of Total Factor Productivity Measurement, Department of Economics, University of British Columbia, Vancouver, Canada, V6T 1 Z1.

Fabrizio Pompei (2016). Determinants of productivity at firm- and industry-level. Economics and Industrial Dynamics (2015/2016). Department of Economics, University of Perugia.

Fekadu Jida, (2010). The economic performance of METABO Share Company, a thesis presented to the department of economics of undergraduate students, AAU.

Freeman, (2008). Labor Productivity Indicators, Comparison of two oecd databases productivity differentials \& the balassa-samuelson effect, 2018.

Fudan SIRPA Think Tank Report Series (2017). Development and Industrialization in Ethiopia, Reflections from China's Experience. School of International Relations and Public Affairs, Fudan University, November 2017.

Getnet \& Admit (2005). The Ethiopian Manufacturing Sector : Competitiveness and the Way Ahead. Institute of Development Research and Economics Department, Addis Ababa University.

Kindeye Fenta ( 2014). Industry and Industrialization in Ethiopia: Policy Dynamics and Spatial Distributions. European Journal of Business and Management, Vol.6, No.34, 2014.

Lawrence R. Klein and Robert Summers (1966). The Wharton Index of Capacity Utilization (the University of Pennsylvania W, Wharton School of Finance and Commerce, Economics Research Unit.

Mandara and Ali (2018). Appraisal of the Impact of Industrialization on Economic Growth in Nigeria, IOSR 
Journal of Business and Management (IOSR-JBM), Volume 20, Issue 1. Ver. V (January. 2018).

Ministry of Industry (2017). Investment Opportunity in Manufacturing Industry, Investment Research, Monitoring, and Support. Prepared by: Investment Research and Promotion Team.

Oqubay A. (2018). The Structure and Performance of the Ethiopian Manufacturing Sector, Working Paper Series No 299, African Development Bank, Abidjan, Côte d'Ivoire.

Oz Shy (1995). Industrial Organization, Theory, and Applications. The MIT Press Cambridge, Massachusetts, London, England.

Rama and Simon (2015). Performance Measurement of manufacturing industries in Ethiopia- an Analytical Study. Journal of Poverty, Investment and Development, Vol.7, 2015.

Simon-Oke (2005). Manufacturing Capacity Utilization and Industrial Development in Nigeria: An Assessment (1976 - 2005). An International Multi-Disciplinary Journal, Ethiopia, Vol. 4 (2) April 2010.

Tamrat .T (2014). The economic performance of Ethiopian brewery industry with reference to s.t George brewery, a thesis presented to the school of undergraduate students in economics, AAU.

UNDP (2017). Manufacturing export performance in Ethiopia. Prepared by Policy Advisory Unit of UNDP Ethiopia.

UNDP (2016). Understanding African experiences in formulating and implementing plans for emergence: Growing Manufacturing Industry in Ethiopia, Case Study. 